\title{
Testing of Replacement Bag Material
}

by

J. E. Laurinat

Westinghouse Savannah River Company

Savannah River Site

Aiken, South Carolina 29808

DOE Contract No. DE-AC09-96SR18500

This paper was prepared in connection with work done under the above contract number with the U.S. Department of Energy. By acceptance of this paper, the publisher and/or recipient acknowledges the U.S. Government's right to retain a nonexclusive, royalty-free license in and to any copyright covering this paper, along with the right to reproduce and to authorize others to reproduce all or part of the copyrighted paper. 


\section{DISCLAIMER}

This report was prepared as an account of work sponsored by an agency of the United States Government. Neither the United States Government nor any agency thereof, nor any of their employees, makes any warranty, express or implied, or assumes any legal liability or responsibility for the accuracy, completeness, or usefulness of any information, apparatus, product, or process disclosed, or represents that its use would not infringe privately owned rights. Reference herein to any specific commercial product, process, or service by trade name, trademark, manufacturer, or otherwise does not necessarily constitute or imply its endorsement, recommendation, or favoring by the United States Government or any agency thereof. The views and opinions of authors expressed herein do not necessarily state or reflect those of the United States Government or any agency thereof.

This report has been reproduced directly from the best available copy.

Available to DOE and DOE contractors from the Office of Scientific and Technical Information, P. O. Box 62, Oak Ridge, TN 37831; prices available from (423) 576-8401.

Available to the public from the National Technical Information Service, U. S. Department of Commerce, 5285 Port Royal Road, Springfield, VA 22161. 


\section{DISCLAIMER}

Portions of this document may be illegible in electronic image products. Images are produced from the best available original document. 


\section{INFORMATION ONLY}

\section{RECORDS}

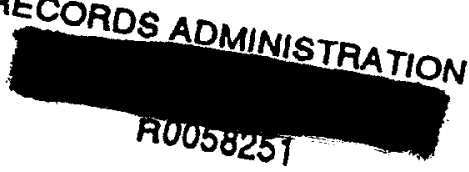

AMC Clekew Sr.EngA 2/2y/58

Authorized Derivative Classifier

Testing of Replacement Bag Material (U)

February 24,1998

Westinghouse Savannah River Company

Aiken, SC 29802

Prepared by the U. S. Department of Energy under Contract DE-AC09-96SR18500 
WSRC-TR-98-00036

Revision 0

Testing of Replacement Bag Materiar(U)

By

J. E. Laurinat

Issued: February 24, 1998

Approvals

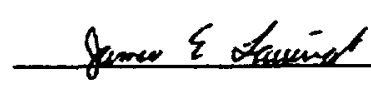

J. E. Laurinat, Author, SMT/C\&HTS
$2 \cdot 24-98$

Date

$2 / 24 / 98$

N. M. Askew, Technical Reviewer, SMT/C\&HTS

Date

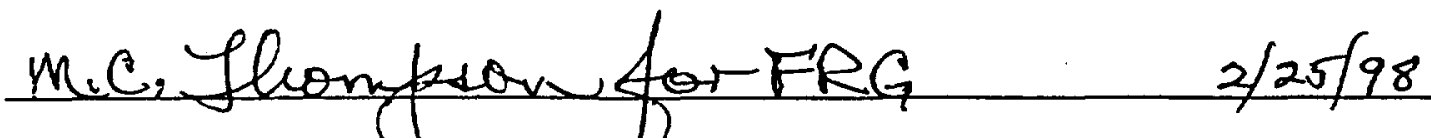

F. R. Graham, Responsible Manager, GMT/C\&HTS

Date

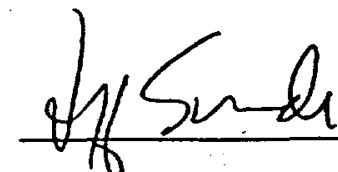

$2-25-98$

J. B. Shade, NMS\&S Engineering

Date 


\section{Table of Contents}

Section

Page

1.0 Introduction and Summary ......................................................... 1-2

2.0 Measurement of the Effect of Irradiation on Material Properties

3.0 Measurement of Outgassing due to Heating 3

4.0 Calculation of Outgassing due to Irradiation $3-4$

5.0 Conclusions and Recommendations 4

6.0 References 4-5

Tables 6

Figures 11

Appendix: Calculation of the Expected Dose and Gas Generation for Plutonium Can Bag Material 13 


\subsection{Introduction and Summary}

Recently, the FB-Line bagout material was changed to simplify the processing of sand, slag, and crucible. The low density polyethylene (LDPE) and polyvinyl chloride (PVC) bags normally used to bag out cans of plutonium-bearing material have been replaced with nylon bags. Since LDPE and PVC are not soluble in the nitric acid dissolver solution used in F-Canyon, the flowsheet called for the existing cans of sand, slag, and crucible to be repackaged before they were added to the dissolver. Unlike LDPE and PVC, nylon is soluble in nitric acid. This allows cans to be packaged using normal practices and charged directly to the dissolver, thus saving handling requirements and personnel exposure [1].

The original nylon replacement material proved to be unsuitable for bagout operations due to a tendency to crack and leak during use [2]. The cracking was attributed to friction caused by a buildup of static electricity as the bags were pulled over the cans. To alleviate this problem and prevent leaks, two replacement materials, a thinner nylon with an antistatic agent added, color coded orange, and a high residual monomer plastic (HRMP), color coded pink, were selected for evaluation as bag materials. The orange bag material is currently being used for packaging; the pink material also has been judged to be acceptable if used with an anti-static agent.

FB-Line Operations has asked for measurement of the effects of radiation and heating on these materials. Specifically, they have requested a comparison of the material properties of the plastics before and after irradiation, a measurement of the amount of outgassing when the plastics are heated, and a calculation of the amount of radiolytic gas generation. Testing was performed on samples of approximately 2 mil thick nylon and 4 mil thick HRMP blown tubing. The samples were taken from material that is currently used or has been proposed for use in FB-Line. Many of the requested tests repeat tests previously performed on the original replacement and LDPE bag materials $[3,4]$.

To evaluate the effect of irradiation on material properties, tensile stresses and elongations to break were compared for unirradiated and irradiated samples. Standard ASTM methods for the measurement of tensile plastic properties [5] and resistance to tear propagation [6] were used. Properties were measured both parallel to the direction of machining (MD) and transverse to the direction of machining (TD). Tensile strength measurements showed that the ultimate strengths of the replacement bag materials decreased by $15-16 \%$ in the MD orientation and $27-28 \%$ in the TD orientation after irradiation with $5 \times 10^{6} \mathrm{rad}$, a dose equivalent to about one year exposure in a plutonium can. Elongations to break also decreased for the HRMP material. Tear measurements gave a similar decrease in the ultimate strengths of the materials and little if any significant change in elongations to break. Although the $5 \times 10^{6}$ dose significantly degraded the properties of the replacement materials, their strengths remained superior to those previously measured for LDPE [4], even after irradiation.

Neither replacement material outgassed appreciably. When samples of both types of materials were heated in a sealed container to the maximum expected storage can temperature of $93^{\circ} \mathrm{C}$, the pressure increased by about $3.0 \mathrm{psi}$. This pressure increase, most if not all of which can be attributed to heating of the air in the container, would not cause a can to fail. Using a representative $G$ value of 1.6 molecules $/ 100 \mathrm{ev}$, the amount of outgassing due to radiolysis was calculated to be negligible.

In conclusion, it may be stated that the results of the strength tests and the outgassing measurements and calculations demonstrate that the proposed replacement nylon bag 
materials (HRMP and orange anti-static material) are acceptable substitutes for LDPE and the original nylon with respect to mechanical properties.

\subsection{Measurement of the Effect of Irradiation on Material Properties}

To determine the effect of irradiation on bag strength, the nylon and high residual monomer bag materials were irradiated to $5 \times 10^{6}$ rad using a Cobalt-60 gamma source. As explained in the Appendix, these exposures are equivalent to the expected doses that the bag material would receive after sealing a plutonium can for about one year.

Irradiated and unirradiated samples were submitted to the SRTC Strategic Materials Technology Section for analyses of tensile properties. Standard ASTM tests were used to measure the tensile strength [5] and resistance to tearing [6]. Elongations to break were also measured for both tests. Test samples were cut from blown sheets of material identical to those used or proposed for use in FB-Line. Figure 1 depicts the samples.

Tests were performed using an Instron Model 1122 mechanical testing frame. Tensile test samples were stretched at a cross-head speed of $50 \mathrm{~mm} / \mathrm{min}$, and tear test samples were pulled apart at a speed of $200 \mathrm{~mm} / \mathrm{min}$.

Tables 1 and 2 report the results of the tensile and tear tests. Tensile test results include upper and lower yield loads, the ultimate load just prior to break, and elongation at break. Tear test results include lower yield and ultimate loads and the elongation at break. Results are statistically analyzed in Tables 3 and 4 . These tables also list statistical analyses of results of previous tensile tests of the LDPE and original replacement bag materials [4]. The statistical analyses show that all replacement materials became weaker and that the HRMP and original nylon replacement materials became somewhat stiffer after irradiation. Tensile strengths of all replacement materials remained superior to those of unirradiated LDPE even after irradiation, however. The average ultimate loads for irradiated samples of the original replacement nylon, the HRMP, and the orange nylon with the anti-static agent were 15.9, 19.6, and $10.0 \mathrm{lbf}$ in the machine direction and 13.2, 18.5 , and $9.3 \mathrm{lbf}$ in the transverse direction, compared to average ultimate loads of $8.2 \mathrm{lbf}$ in the machine direction and $4.2 \mathrm{lbf}$ in the transverse direction for unirradiated LDPE. (The tensile strength of the orange nylon material was lower than that of the original nylon material because of its reduced thickness, 2 mils versus 3-4 mil.)

The tear samples pulled apart at much lower loads than the tensile samples. The load measurements for the tear tests have large uncertainties because the instrument was operating at the lower end of its range, which is 0 to $10 \mathrm{lbf}$. Nevertheless, there were statistically significant decreases in tear resistances, ranging from $10 \%$ to $42 \%$, after irradiation.

The increase in stiffness after irradiation is probably due to radiation-induced cross linking of the nylon fibers. The unirradiated samples exhibited oscillations in the load as they were stretched. This behavior was attributed to breaking and reformation of bonds between plastic fibers. These oscillations largely disappeared after irradiation, indicating that radiation-induced cross-linking may have acted to heal defects in the plastic. This effect would counteract stiffening and weakening of the plastics caused by irradiation. 


\subsection{Measurement of Outgassing due to Heating}

A series of tests was conducted in which samples of the replacement bag materials were placed inside another closed vessel and heated to about $93^{\circ} \mathrm{C}$ inside a drying furnace [8]. Pressures were measured by a 0-30 psig dial pressure gauge. The entire assembly, including the pressure gauge, was heated inside the furnace. Three tests were conducted, one each with HRMP and the orange nylon samples, and one for calibration, with a small amount of water in the closed vessel. Theoretically, the calibration test should register an increase equal to the sum of the water vapor pressure and the increase due to volumetric expansion. The two tests with the plastic samples should give equilibrium pressure increases equal to the sum of the increase from volumetric expansion and the vapor pressure of condensable gases released by the plastic at the test temperature. Thus, for a sufficiently large sample, the pressure generated by heating the plastic should not depend on the amount of plastic in the container. Relatively large pieces of HRMP and nylon were used to ensure that the vapor space became saturated with offgasses from the plastic. HRMP and nylon samples weighing 0.79 and 1.49 grams, respectively, were heated in the $25-\mathrm{cm}^{3}$ test chamber. The weight-to-volume ratios for these tests, 0.032 and 0.060 grams $/ \mathrm{cm}^{3}$, exceeded the estimated weight-to-volume ratio for a bag inside the plutonium can, which is $12 \mathrm{grams} / 631 \mathrm{~cm}^{3}$, or $0.019 \mathrm{grams} / \mathrm{cm}^{3}$.

Figure 2 depicts transient pressure measurements for the outgassing tests. A comparison between measured and expected results for the water vapor calibration test demonstrates that these measurements are at least approximately correct. Theoretically, the equilibrium pressure for this test should be the sum of the increase due to heating of the air initially in the vessel and the vapor pressure of water. The pressure should increase 3.5 psi due to the temperature increase from room temperature, and 11.5 psi due to evaporation of water at the $93^{\circ} \mathrm{C}$ test temperature [9], for a total of $15.0 \mathrm{psi}$. The measured pressure rise for the calibration test was 15.5 psi. The plastic samples generated equilibrium pressure increases of about 2.9 psi, slightly less than what would be expected for air alone. This demonstrates that there is little if any outgassing from these plastics when they are heated to this temperature. The difference between the measured pressure increases and the increase predicted for heating of air probably can be attributed to pressure gauge errors.

\subsection{Calculation of Outgassing due to Irradiation}

The amount of outgassing from the nylon bag material due to irradiation has been calculated based on the irradiation level and an estimated G-value for gas generation. A calculation was performed in lieu of a measurement because the volume of gas that would be generated is too small to measure with existing site equipment. In a separate study, measurements under vacuum gave G-values ranging up to 1.6 molecules/100 ev for various types of nylon [10]; this highest cited value is used in the calculations for both HRMP and nylon. Two-thirds of the gas that was generated was hydrogen, and most of the remainder was carbon monoxide.

With an assumed G-value of 1.6 molecules/100 ev, a plutonium can bag is calculated to generate only about $2.5 \mathrm{~cm}^{3}$ of vapor in a service time of 1 year, based on a decay rate of $1 \times 10^{9}$ disintegrations $/ \mathrm{min} / 100 \mathrm{~cm}^{2}$, or a total exposure of $5 \times 10^{6} \mathrm{rad}$. This volume is insignificant compared to the air space enclosing the bags between the inner and outer plutonium cans, so there should not be a significant pressure increase due to radiolytic outgassing. The volume between the two cans has been measured to be $631 \mathrm{~cm}^{3}$; the 
calculated radiolytic gas generation is only $0.4 \%$ of this total. The Appendix presents details of the calculation of the amount of gas generation.

\subsection{Conclusions and Recommendations}

To evaluate the effect of irradiation on material properties, tensile stresses and elongations to break were compared for unirradiated and irradiated samples, using standard ASTM methods for the measurement of tensile plastic properties and resistance to tear propagation. Properties were measured both parallel to the direction of machining (MD) and transverse to the direction of machining (TD). Tensile strength measurements showed that the ultimate strengths of the replacement bag materials decreased by $15-16 \%$ in the MD orientation and $27-28 \%$ in the TD orientation after irradiation with $5 \times 10^{6}$ rad, a dose equivalent to about one year exposure in a plutonium can. Elongations to break also decreased for the HRMP material. Tear measurements gave a similar decrease in the ultimate strengths of the materials and little if any significant change in elongations to break. Although the $5 \times 10^{6}$ dose significantly degraded the properties of the replacement materials, their strengths remained superior to those previously measured for LDPE, even after irradiation.

Neither replacement material outgassed appreciably. When samples of both types of materials were heated in a sealed container to the maximum expected storage can temperature of $93^{\circ} \mathrm{C}$, the pressure increased by about 2.9 psi. This pressure increase, most if not all of which can be attributed to heating of the air in the container, would not cause a can to fail. Using a representative $G$ value of 1.6 molecules $/ 100 \mathrm{ev}$, the amount of outgassing due to radiolysis was calculated to be negligible.

In conclusion, it may be stated that the results of the strength tests and the outgassing measurements and calculations demonstrate that the proposed replacement bag materials (HRMP and orange anti-static material) are an acceptable substitute for LDPE with respect to mechanical properties.

\subsection{References}

1. R. A. Pierce, "Testing of Acid-Soluble Plastics for SS\&C Processing in F-Canyon," SRT-CTS-96-0120, November 19, 1996.

2. R. A. Pierce, "Replacement Nylon Testing," SRT-CHT-97-2036, December 30, 1997.

3. M. J. Morgan, "Mechanical Properties of Irradiated Nylon," SRT-MTS-97-3012, July 15, 1997.

4. J. E. Laurinat, "Testing of Nylon Bag Material (U)," WSRC-TR-97-0244, Rev. 0, July 15, 1997.

5. ASTM D638-89, "Standard Test Method for Tensile Properties of Plastics," Annual Book of ASTM Standards, Vol. 8.01, 1989.

6. ASTM D1938-93, "Standard Test Method for Tear-Propagation Resistance of Plastic Film and Thin Sheeting by a Single-Tear Method," Annual Book of ASTM Standards, Vol. 8.02, 1994. 


\subsection{References (continued)}

7. D. R. Lide, ed., CRC Handbook of Chemistry and Physics, 75th ed., CRC Press, Boca Raton (1995), p. A-105.

8. J. E. Laurinat, Laboratory Notebook WSRC-NB-92-42, p. 141.

9. R. H. Perry and D. W. Green, eds., Perry's Chemical Engineers' Handbook, 6th ed. McGraw-Hill, New York (1984), p. 3-237.

10. M. Dole, ed., The Radiation Chemistry of Macromolecules, Vol. II, Academic Press, New York (1973), p. 122.

11. D. R. Lide, ed., CRC Handbook of Chemistry and Physics, 75th ed., CRC Press, Boca Raton (1995), p. 11-33. 
Table 1. Tensile Stress and Elongation Measurements for Plastic Materials

\begin{tabular}{|c|c|c|c|c|c|c|c|c|c|c|c|}
\hline Material & Orientation & $\begin{array}{l}\text { Dose } \\
\text { (Rad) }\end{array}$ & $\begin{array}{l}\text { Gauge } \\
\text { Length } \\
\text { (in) }\end{array}$ & $\begin{array}{l}\text { Width } \\
\text { (in) }\end{array}$ & $\begin{array}{l}\text { Thickness } \\
\text { (in) }\end{array}$ & $\begin{array}{l}\text { Upper } \\
\text { Yield } \\
\text { Load } \\
\text { (bf) }\end{array}$ & $\begin{array}{l}\text { Lower } \\
\text { Yield } \\
\text { Load } \\
\text { (lbf) }\end{array}$ & $\begin{array}{l}\text { Ultimate } \\
\text { Tensile } \\
\text { Load } \\
\text { (lbf) }\end{array}$ & $\begin{array}{l}\text { Elongation } \\
\text { at Break } \\
(\mathrm{mm})\end{array}$ & $\begin{array}{l}\text { Elongation } \\
\text { at Break } \\
(\%)\end{array}$ & $\begin{array}{l}\text { Failure } \\
\text { Location }\end{array}$ \\
\hline $\begin{array}{l}\text { HRMP } \\
\text { HRMP } \\
\text { HRMP } \\
\text { HRMP } \\
\text { HRMP }\end{array}$ & $\begin{array}{l}\text { TD } \\
\text { TD } \\
\text { TD } \\
\text { TD } \\
\text { TD }\end{array}$ & $\begin{array}{l}\text { None } \\
\text { None } \\
\text { None } \\
\text { None } \\
\text { None }\end{array}$ & $\begin{array}{l}5.313 \\
5.039 \\
5.141 \\
5.184 \\
5.234\end{array}$ & $\begin{array}{l}0.7081 \\
0.7354 \\
0.7448 \\
0.7442 \\
0.7512\end{array}$ & $\begin{array}{l}0.0038 \\
0.0036 \\
0.0038 \\
0.0040 \\
0.0042\end{array}$ & $\begin{array}{l}16.6 \\
18.0 \\
18.6 \\
18.1 \\
18.2\end{array}$ & $\begin{array}{l}14.9 \\
16.4 \\
16.8 \\
15.5 \\
16\end{array}$ & $\begin{array}{l}24.0 \\
20.2 \\
27.0 \\
27.5 \\
27.5\end{array}$ & $\begin{array}{l}383.6 \\
193.0 \\
433.0 \\
460.3 \\
467.8\end{array}$ & $\begin{array}{l}284 \\
151 \\
332 \\
350 \\
352\end{array}$ & $\begin{array}{l}\text { reduced section } \\
\text { shoulder } \\
\text { reduced section } \\
\text { reduced section } \\
\text { reduced section }\end{array}$ \\
\hline $\begin{array}{l}\text { HRMP } \\
\text { HRMP } \\
\text { HRMP } \\
\text { HRMP } \\
\text { HRMP }\end{array}$ & $\begin{array}{l}\text { MD } \\
M D \\
M D \\
M D \\
M D\end{array}$ & $\begin{array}{l}\text { None } \\
\text { None } \\
\text { None } \\
\text { None } \\
\text { None }\end{array}$ & $\begin{array}{l}5.397 \\
5.345 \\
5.283 \\
5.294 \\
5.212\end{array}$ & $\begin{array}{l}0.7298 \\
0.7396 \\
0.7497 \\
0.73 \\
0.7293\end{array}$ & $\begin{array}{l}0.0038 \\
0.0040 \\
0.0040 \\
0.0040 \\
0.0040\end{array}$ & $\begin{array}{l}18.8 \\
19.0 \\
18.5 \\
18.7 \\
17.4\end{array}$ & $\begin{array}{l}18.1 \\
18.4 \\
18 \\
18.2 \\
16.9\end{array}$ & $\begin{array}{l}21.0 \\
23.0 \\
24.0 \\
22.0 \\
25.5\end{array}$ & $\begin{array}{l}251.0 \\
292.1 \\
331.0 \\
272.5 \\
431.2\end{array}$ & $\begin{array}{l}183 \\
215 \\
247 \\
203 \\
326\end{array}$ & $\begin{array}{l}\text { shoulder } \\
\text { shoulder } \\
\text { shoulder } \\
\text { reduced section } \\
\text { reduced section }\end{array}$ \\
\hline $\begin{array}{l}\text { HRMP } \\
\text { HRMP } \\
\text { HRMP } \\
\text { HRMP } \\
\text { HRMP }\end{array}$ & $\begin{array}{l}\text { TD } \\
\text { TD } \\
\text { TD } \\
\text { TD } \\
\text { TD }\end{array}$ & $\begin{array}{l}5 \times 10^{46} \\
5 \times 10^{46} \\
5 \times 10^{4} 6 \\
5 \times 10^{46} \\
5 \times 10^{46}\end{array}$ & $\begin{array}{l}5.091 \\
5.292 \\
5.324 \\
5.294 \\
5.277\end{array}$ & $\begin{array}{l}0.7406 \\
0.735 \\
0.738 \\
0.7762 \\
0.7348\end{array}$ & $\begin{array}{l}0.0042 \\
0.0040 \\
0.0040 \\
0.0040 \\
0.0040\end{array}$ & $\begin{array}{l}16.4 \\
15.4 \\
15.5 \\
13.7 \\
12.9\end{array}$ & $\begin{array}{l}14.8 \\
14 \\
14.2 \\
13.1 \\
12.6\end{array}$ & $\begin{array}{l}21.0 \\
18.2 \\
18.0 \\
19.2 \\
16.2\end{array}$ & $\begin{array}{l}326.4 \\
277.1 \\
220.0 \\
318.4 \\
255.1\end{array}$ & $\begin{array}{l}252 \\
206 \\
163 \\
237 \\
190\end{array}$ & $\begin{array}{l}\text { shoulder } \\
\text { reduced section } \\
\text { shoulder } \\
\text { reduced section } \\
\text { shoulder }\end{array}$ \\
\hline $\begin{array}{l}\text { HRMP } \\
\text { HRMP } \\
\text { HRMP } \\
\text { HRMP } \\
\text { HRMP }\end{array}$ & $\begin{array}{l}\text { MD } \\
\text { MD } \\
\text { MD } \\
M D \\
M D\end{array}$ & $\begin{array}{l}5 \times 10^{46} \\
5 \times 10^{46} \\
5 \times 10^{46} \\
5 \times 10^{46} \\
5 \times 10^{46}\end{array}$ & $\begin{array}{l}5.406 \\
5.295 \\
5.188 \\
5.156 \\
5.053\end{array}$ & $\begin{array}{l}0.7502 \\
0.7308 \\
0.743 \\
0.7196 \\
0.7476\end{array}$ & $\begin{array}{l}0.0040 \\
0.0040 \\
0.0040 \\
0.0040 \\
0.0040\end{array}$ & $\begin{array}{l}16.6 \\
15.8 \\
19.0 \\
15.2 \\
14.6\end{array}$ & $\begin{array}{l}15.2 \\
18.7 \\
15.2 \\
14.6\end{array}$ & $\begin{array}{l}18.4 \\
22.0 \\
19.8 \\
18.0\end{array}$ & $\begin{array}{l}270.7 \\
242.0 \\
270.3 \\
229.0\end{array}$ & $\begin{array}{l}201 \\
184 \\
206 \\
178\end{array}$ & $\begin{array}{l}\text { reject } \\
\text { reduced section } \\
\text { reduced section } \\
\text { reduced section } \\
\text { shoulder }\end{array}$ \\
\hline $\begin{array}{l}\text { Nylon } \\
\text { Nylon } \\
\text { Nylon } \\
\text { Nylon } \\
\text { Nylon }\end{array}$ & $\begin{array}{l}\text { TD } \\
\text { TD } \\
\text { TD } \\
\text { TD } \\
\text { TD }\end{array}$ & $\begin{array}{l}\text { None } \\
\text { None } \\
\text { None } \\
\text { None } \\
\text { None }\end{array}$ & $\begin{array}{l}5.229 \\
5.334 \\
5.223 \\
5.201 \\
5.327\end{array}$ & $\begin{array}{l}0.7132 \\
0.72 \\
0.7074 \\
0.7104 \\
0.728\end{array}$ & $\begin{array}{l}0.0020 \\
0.0020 \\
0.0020 \\
0.0020 \\
0.0020\end{array}$ & $\begin{array}{l}11.6 \\
13.4 \\
13.0 \\
12.3 \\
12.8\end{array}$ & $\begin{array}{r}9.8 \\
10.6 \\
10.4 \\
9.8\end{array}$ & $\begin{array}{l}12.5 \\
13.2 \\
13.4 \\
12.3\end{array}$ & $\begin{array}{l}177.3 \\
101.0 \\
105.3\end{array}$ & $\begin{array}{r}133 \\
75 \\
79\end{array}$ & $\begin{array}{l}\text { reduced section } \\
\text { shoulder } \\
\text { reduced section } \\
\text { reject } \\
\text { reject }\end{array}$ \\
\hline $\begin{array}{l}\text { Nylon } \\
\text { Nylon } \\
\text { Nylon } \\
\text { Nylon } \\
\text { Nylon }\end{array}$ & $\begin{array}{l}M D \\
M D \\
M D \\
M D \\
M D\end{array}$ & $\begin{array}{l}\text { None } \\
\text { None } \\
\text { None } \\
\text { None } \\
\text { None }\end{array}$ & $\begin{array}{l}5.189 \\
5.307 \\
5.327 \\
5.376 \\
5.258\end{array}$ & $\begin{array}{l}0.7088 \\
0.7066 \\
0.703 \\
0.7156 \\
0.7092\end{array}$ & $\begin{array}{l}0.0020 \\
0.0020 \\
0.0020 \\
0.0020 \\
0.0020\end{array}$ & $\begin{array}{l}11.5 \\
11.4 \\
11.2 \\
11.4 \\
12.0\end{array}$ & $\begin{array}{l}11.4 \\
11.2 \\
11.1 \\
11.2 \\
11.9\end{array}$ & $\begin{array}{l}11.5 \\
11.6 \\
12.0 \\
11.8 \\
13.2\end{array}$ & $\begin{array}{l}121.1 \\
151.9 \\
181.0 \\
142.7 \\
196.6\end{array}$ & $\begin{array}{r}92 \\
113 \\
134 \\
105 \\
147\end{array}$ & $\begin{array}{l}\text { shoulder } \\
\text { reduced section } \\
\text { reduced section } \\
\text { shoulder } \\
\text { reduced section }\end{array}$ \\
\hline
\end{tabular}


Table 1. Tensile Stress and Elongation Measurements for Plastic Materials (continued)

\begin{tabular}{|c|c|c|c|c|c|c|c|c|c|c|c|}
\hline Material & Orientation & $\begin{array}{l}\text { Dose } \\
\text { (Rad) }\end{array}$ & $\begin{array}{l}\text { Gauge } \\
\text { Length } \\
\text { (in) }\end{array}$ & $\begin{array}{l}\text { Width } \\
\text { (in) }\end{array}$ & $\begin{array}{l}\text { Thickness } \\
\text { (in) }\end{array}$ & $\begin{array}{l}\text { Upper } \\
\text { Yield } \\
\text { Load } \\
\text { (lbf) }\end{array}$ & $\begin{array}{l}\text { Lower } \\
\text { Yield } \\
\text { Load } \\
\text { (lbf) }\end{array}$ & $\begin{array}{l}\text { Ultimate } \\
\text { Tensile } \\
\text { Load } \\
\text { (lbf) }\end{array}$ & $\begin{array}{l}\text { Elongation } \\
\text { at Break } \\
(\mathrm{mm})\end{array}$ & $\begin{array}{l}\text { Elongation } \\
\text { at Break } \\
(\%)\end{array}$ & $\begin{array}{l}\text { Failure } \\
\text { Location }\end{array}$ \\
\hline Nylon & TD & $5 \times 1046$ & 5.222 & 0.6778 & 0.0020 & 11.1 & 8.6 & 11.2 & 73.6 & 55 & reduced section \\
\hline Nylon & $\mathrm{TD}$ & $5 \times 1006$ & 5.084 & 0.72 & 0.0020 & 11.1 & 9.6 & 11.1 & 38.3 & 30 & shoulder \\
\hline Nylon & TD & $5 \times 10^{4} 6$ & 5.285 & 0.7002 & 0.0020 & 8.4 & 8.0 & 8.4 & 99.0 & 74 & shoulder \\
\hline Nylon & TD & $5 \times 10^{\wedge} 6$ & 5.395 & 0.6623 & 0.0020 & 7.3 & 6.8 & 7.6 & 183.0 & 134 & reduced section \\
\hline Nylon & TD & $5 \times 10^{96} 6$ & 5.371 & 0.731 & 0.0020 & 8.0 & 7.5 & 8.2 & 194.7 & 143 & shoulder \\
\hline Nylon & $M D$ & $5 \times 10^{4} 6$ & 5.346 & 0.7486 & 0.0020 & 10.1 & 9.9 & 11.1 & 228.0 & 168 & shoulder \\
\hline Nylon & $M D$ & $5 \times 10^{\wedge 6}$ & 5.119 & 0.71 & 0.0020 & 10.6 & 10.6 & 10.8 & 116.0 & 89 & shoulder \\
\hline Nylon & MD & $5 \times 10^{\wedge} 6$ & 5.384 & 0.7272 & 0.0020 & 7.8 & 8.3 & 8.3 & 132.3 & 97 & reduced section \\
\hline Nylon & MD & $5 \times 10^{4} 6$ & 5.224 & 0.7182 & 0.0020 & 7.4 & 7.4 & 10.0 & 262.9 & 198 & reduced section \\
\hline Nylon & MD & $5 \times 10^{\wedge 6}$ & 5.266 & 0.715 & 0.0020 & 7.4 & 7.4 & 10.0 & 262.3 & 196 & shoulder \\
\hline
\end{tabular}

Table 2. Tear Stress and Elongation Measurements for Plastic Materials

\begin{tabular}{|c|c|c|c|c|c|c|c|c|c|}
\hline Material & Orientation & Dose & $\begin{array}{l}\text { Gauge } \\
\text { Length (in) }\end{array}$ & $\begin{array}{l}\text { Width } \\
\text { (in) }\end{array}$ & $\begin{array}{l}\text { Thickness } \\
\text { (in) }\end{array}$ & $\begin{array}{l}\text { Initial Tear } \\
\text { Load (lbf) }\end{array}$ & $\begin{array}{l}\text { Ultimate } \\
\text { Load (bf) }\end{array}$ & $\begin{array}{l}\text { Elongation } \\
(\mathrm{mm})\end{array}$ & $\begin{array}{l}\text { Elongatio } \\
(\%)\end{array}$ \\
\hline $\begin{array}{l}\text { HRMP } \\
\text { HRMP } \\
\text { HRMP } \\
\text { HRMP } \\
\text { HRMP }\end{array}$ & $\begin{array}{l}T D \\
T D \\
T D \\
T D \\
T D\end{array}$ & $\begin{array}{l}\text { None } \\
\text { None } \\
\text { None } \\
\text { None } \\
\text { None }\end{array}$ & $\begin{array}{l}2.03 \\
2.06 \\
2.02 \\
2.07 \\
1.99\end{array}$ & $\begin{array}{l}1.02 \\
1.03 \\
1.03 \\
1.01 \\
1.03\end{array}$ & $\begin{array}{l}0.0040 \\
0.0040 \\
0.0040 \\
0.0038 \\
0.0034\end{array}$ & $\begin{array}{l}0.36 \\
0.30 \\
0.30 \\
0.35 \\
0.35\end{array}$ & $\begin{array}{l}0.55 \\
0.50 \\
0.55 \\
0.55 \\
0.60\end{array}$ & $\begin{array}{l}60.2 \\
56.6 \\
56.3 \\
55.8 \\
59.0\end{array}$ & $\begin{array}{l}117 \\
108 \\
110 \\
106 \\
117\end{array}$ \\
\hline $\begin{array}{l}\text { HRMP } \\
\text { HRMP } \\
\text { HRMP } \\
\text { HRMP } \\
\text { HRMP }\end{array}$ & $\begin{array}{l}M D \\
M D \\
M D \\
M D \\
M D\end{array}$ & $\begin{array}{l}\text { None } \\
\text { None } \\
\text { None } \\
\text { None } \\
\text { None }\end{array}$ & $\begin{array}{l}2.08 \\
1.97 \\
2.06 \\
2.04 \\
2.12\end{array}$ & $\begin{array}{l}0.99 \\
1.03 \\
1.02 \\
1.02 \\
1.06\end{array}$ & $\begin{array}{l}0.0038 \\
0.0040 \\
0.0040 \\
0.0040 \\
0.0040\end{array}$ & $\begin{array}{l}0.30 \\
0.30 \\
0.30 \\
0.35 \\
0.35\end{array}$ & $\begin{array}{c}0.40 \\
0.40 \\
\text { Rejected } \\
0.40 \\
0.45\end{array}$ & $\begin{array}{r}\text { Rejected } \\
54.6 \\
53.9 \\
51.9\end{array}$ & $\begin{array}{r}109 \\
104 \\
97\end{array}$ \\
\hline $\begin{array}{l}\text { HRMP } \\
\text { HRMP } \\
\text { HRMP } \\
\text { HRMP } \\
\text { HRMP }\end{array}$ & $\begin{array}{l}\text { TD } \\
\text { TD } \\
\text { TD } \\
\text { TD } \\
\text { TD }\end{array}$ & $\begin{array}{l}5 \times 10^{-6} 6 \\
5 \times 10^{-6} \\
5 \times 10^{-6} 6 \\
5 \times 10^{-6} 6 \\
5 \times 10^{-16}\end{array}$ & $\begin{array}{l}1.99 \\
2.03 \\
2.06 \\
2.02 \\
2.08\end{array}$ & $\begin{array}{l}1.05 \\
1.03 \\
1.03 \\
1.00 \\
1.03\end{array}$ & $\begin{array}{l}0.0040 \\
0.0040 \\
0.0040 \\
0.0040 \\
0.0040\end{array}$ & $\begin{array}{l}0.30 \\
0.25 \\
0.30 \\
0.35\end{array}$ & $\begin{array}{l}0.40 \\
0.40 \\
0.40 \\
0.45 \\
0.40\end{array}$ & $\begin{array}{l}57.9 \\
53.0 \\
57.3 \\
59.7 \\
58.2\end{array}$ & $\begin{array}{l}115 \\
103 \\
110 \\
116 \\
110\end{array}$ \\
\hline
\end{tabular}


Table 2. Tear Stress and Elongation Measurements for Plastic Materials (continued)

\begin{tabular}{|c|c|c|c|c|c|c|c|c|c|c|}
\hline & Material & Orientation & Dose & $\begin{array}{l}\text { Gauge } \\
\text { Length (in) }\end{array}$ & $\begin{array}{l}\text { Width } \\
\text { (in) }\end{array}$ & $\begin{array}{l}\text { Thickness } \\
\text { (in) }\end{array}$ & $\begin{array}{l}\text { Initial Tear } \\
\text { Load (lbf) }\end{array}$ & $\begin{array}{l}\text { Ultimate } \\
\text { Load (lbf) }\end{array}$ & $\begin{array}{l}\text { Elongation } \\
(\mathrm{mm})\end{array}$ & $\begin{array}{l}\text { Elongation } \\
(\%)\end{array}$ \\
\hline & $\begin{array}{l}\text { HRMP } \\
\text { HRMP } \\
\text { HRMP } \\
\text { HRMP } \\
\text { HRMP }\end{array}$ & $\begin{array}{l}M D \\
M D \\
M D \\
M D \\
M D\end{array}$ & $\begin{array}{l}5 \times 10^{\wedge} 6 \\
5 \times 10^{\wedge} 6 \\
5 \times 10^{\wedge} 6 \\
5 \times 10^{\wedge} 6 \\
5 \times 10^{\wedge} 6\end{array}$ & $\begin{array}{l}2.03 \\
2.06 \\
2.02 \\
2.02 \\
2.03\end{array}$ & $\begin{array}{l}1.02 \\
1.02 \\
1.04 \\
1.03 \\
1.04\end{array}$ & $\begin{array}{l}0.0040 \\
0.0040 \\
0.0040 \\
0.0040 \\
0.0040\end{array}$ & $\begin{array}{l}0.30 \\
0.25 \\
0.20 \\
0.30 \\
0.20\end{array}$ & $\begin{array}{l}0.38 \\
0.35 \\
0.35 \\
0.35 \\
0.35\end{array}$ & $\begin{array}{l}56.1 \\
62.2 \\
62.1 \\
61.9 \\
53.0\end{array}$ & $\begin{array}{l}109 \\
119 \\
121 \\
120 \\
103\end{array}$ \\
\hline & $\begin{array}{l}\text { Nylon } \\
\text { Nylon } \\
\text { Nylon } \\
\text { Nylon } \\
\text { Nylon }\end{array}$ & $\begin{array}{l}\text { MD } \\
M D \\
M D \\
M D \\
M D\end{array}$ & $\begin{array}{l}\text { None } \\
\text { None } \\
\text { None } \\
\text { None } \\
\text { None }\end{array}$ & $\begin{array}{l}2.01 \\
2.02 \\
2.11 \\
2.08 \\
2.03\end{array}$ & $\begin{array}{l}1.02 \\
1.03 \\
1.03 \\
1.04 \\
1.04\end{array}$ & $\begin{array}{l}0.0020 \\
0.0020 \\
0.0020 \\
0.0020 \\
0.0020\end{array}$ & $\begin{array}{l}0.13 \\
0.15 \\
0.15 \\
0.15 \\
0.15\end{array}$ & $\begin{array}{l}0.15 \\
0.20 \\
0.20 \\
0.20 \\
0.20\end{array}$ & $\begin{array}{l}53.6 \\
55.7 \\
55.5 \\
49.4 \\
48.3\end{array}$ & $\begin{array}{r}105 \\
108 \\
104 \\
94 \\
94\end{array}$ \\
\hline & $\begin{array}{l}\text { Nylon } \\
\text { Nylon } \\
\text { Nylon } \\
\text { Nylon } \\
\text { Nylon }\end{array}$ & $\begin{array}{l}T D \\
T D \\
T D \\
T D \\
T D\end{array}$ & $\begin{array}{l}5 \times 10^{\wedge} 6 \\
5 \times 10^{4} 6 \\
5 \times 10^{\wedge} 6 \\
5 \times 10^{\wedge} 6 \\
5 \times 10^{\wedge} 6\end{array}$ & $\begin{array}{l}2.01 \\
2.01 \\
2.06 \\
2.01 \\
2.05\end{array}$ & $\begin{array}{l}1.03 \\
1.02 \\
1.00 \\
1.01 \\
0.97\end{array}$ & $\begin{array}{l}0.0020 \\
0.0020 \\
0.0020 \\
0.0020 \\
0.0020\end{array}$ & $\begin{array}{l}0.10 \\
0.10 \\
0.15 \\
0.15 \\
0.10\end{array}$ & $\begin{array}{l}0.30 \\
0.30 \\
0.30 \\
0.30 \\
0.25\end{array}$ & $\begin{array}{l}57.4 \\
58.0 \\
52.6 \\
55.0 \\
55.7\end{array}$ & $\begin{array}{l}112 \\
114 \\
101 \\
108 \\
107\end{array}$ \\
\hline & $\begin{array}{l}\text { Nylon } \\
\text { Nylon } \\
\text { Nylon } \\
\text { Nylon } \\
\text { Nylon }\end{array}$ & $\begin{array}{l}M D \\
M D \\
M D \\
M D \\
M D\end{array}$ & $\begin{array}{l}5 \times 10^{\wedge} 6 \\
5 \times 10^{\wedge} 6 \\
5 \times 10^{4} 6 \\
5 \times 10^{4} 6 \\
5 \times 10^{\wedge} 6\end{array}$ & $\begin{array}{l}2.06 \\
2.07 \\
2.03 \\
2.04 \\
2.07\end{array}$ & $\begin{array}{l}1.03 \\
1.03 \\
1.02 \\
1.02 \\
1.02\end{array}$ & $\begin{array}{l}0.0020 \\
0.0020 \\
0.0020 \\
0.0020 \\
0.0020\end{array}$ & $\begin{array}{l}0.13 \\
0.13 \\
0.13 \\
0.10 \\
0.13\end{array}$ & $\begin{array}{l}0.15 \\
0.15 \\
0.15 \\
0.15 \\
0.15\end{array}$ & $\begin{array}{l}54.2 \\
55.8 \\
54.7 \\
54.7 \\
53.7\end{array}$ & $\begin{array}{l}104 \\
106 \\
106 \\
106 \\
102\end{array}$ \\
\hline
\end{tabular}


Table 3. Effect of $5 \times 10^{6}$ Rad Irradiation on Material Properties

\begin{tabular}{|c|c|c|c|c|c|c|}
\hline $\begin{array}{l}\text { Material/ } \\
\text { Orientation }\end{array}$ & $\begin{array}{l}\text { Test } \\
\text { Type }\end{array}$ & $\begin{array}{l}\text { Dose } \\
\text { (rad) }\end{array}$ & $\begin{array}{l}\text { Upper } \\
\text { Yield } \\
\text { Load } \\
\text { (lbf) }\end{array}$ & $\begin{array}{l}\text { Lower } \\
\text { Yield } \\
\text { Load } \\
\text { (lbf) }\end{array}$ & $\begin{array}{l}\text { Ultimate } \\
\text { Load } \\
\text { (lbf) }\end{array}$ & $\begin{array}{l}\text { Elongatior } \\
\text { to Break } \\
(\%)\end{array}$ \\
\hline HRMP/MD & Tensile & None & $18.5 \pm 0.6$ & $17.9 \pm 0.6$ & $23.1 \pm 1.7$ & $235 \pm 56$ \\
\hline $\begin{array}{l}\text { HRMP/MD } \\
\text { HRMP/TD }\end{array}$ & $\begin{array}{l}\text { Tensile } \\
\text { Tensile }\end{array}$ & $\begin{array}{l}5 \times 10^{6} \\
\text { None }\end{array}$ & $\begin{array}{l}16.2 \pm 1.7 \\
17.9 \pm 0.8\end{array}$ & $\begin{array}{l}15.9 \pm 1.9 \\
15.9 \pm 0.7\end{array}$ & $\begin{array}{l}19.6 \pm 1.8 \\
25.2 \pm 3.2\end{array}$ & $\begin{array}{l}192 \pm 13 \\
294 \pm 84\end{array}$ \\
\hline HRMP/TD & Tensile & $5 \times 10^{6}$ & $14.8 \pm 1.4$ & $13.7 \pm 0.9$ & $18.5 \pm 1.8$ & $210 \pm 36$ \\
\hline Nylon/MD & Tensile & None & $11.5 \pm 0.3$ & $11.4 \pm 0.3$ & $12.0 \pm 0.7$ & $118 \pm 22$ \\
\hline $\begin{array}{l}\text { Nylon/MD } \\
\text { Nylon/TD }\end{array}$ & $\begin{array}{l}\text { Tensile } \\
\text { Tensile }\end{array}$ & $\begin{array}{l}5 \times 10^{6} \\
\text { None }\end{array}$ & $\begin{array}{r}8.7 \pm 1.6 \\
12.6 \pm 0.7\end{array}$ & $\begin{array}{r}8.7 \pm 1.5 \\
10.2 \pm 0.4\end{array}$ & $\begin{array}{l}10.0 \pm 1.1 \\
12.9 \pm 0.5\end{array}$ & $\begin{array}{r}150 \pm 53 \\
96 \pm 33\end{array}$ \\
\hline Nylon/TD & Tensile & $5 \times 10^{6}$ & $9.2 \pm 1.8$ & $8.1 \pm 1.1$ & $9.3 \pm 1.7$ & $87 \pm 49$ \\
\hline HRMP/MD & Tear & None & $-\cdots$ & $0.33 \pm 0.03$ & $0.42 \pm 0.03$ & $103 \pm 6$ \\
\hline $\begin{array}{l}\text { HRMP/MD } \\
\text { HRMP/TD }\end{array}$ & $\begin{array}{l}\text { Tear } \\
\text { Tear }\end{array}$ & $\begin{array}{l}5 \times 10^{6} \\
\text { None }\end{array}$ & ---- & $\begin{array}{l}0.25 \pm 0.05 \\
0.33 \pm 0.03\end{array}$ & $\begin{array}{l}0.36 \pm 0.01 \\
0.55 \pm 0.04\end{array}$ & $\begin{array}{l}114 \pm 8 \\
112 \pm 5\end{array}$ \\
\hline HRMP/TD & Tear & $5 \times 10^{6}$ & $\cdots$ & $0.30 \pm 0.04$ & $0.41 \pm 0.02$ & $111 \pm 5$ \\
\hline $\begin{array}{l}\text { Nylon/MD } \\
\text { Nylon/MD } \\
\text { Nylon/TD }\end{array}$ & $\begin{array}{l}\text { Tear } \\
\text { Tear } \\
\text { Tear }\end{array}$ & $\begin{array}{l}\text { None } \\
5 \times 10^{6} \\
\text { None }\end{array}$ & -.-- & $\begin{array}{l}0.15 \pm 0.01 \\
0.12 \pm 0.01 \\
0.21 \pm 0.04\end{array}$ & $\begin{array}{l}0.19 \pm 0.02 \\
0.15 \pm 0.00 \\
0.30 \pm 0.03\end{array}$ & $\begin{array}{l}101 \pm 7 \\
105 \pm 2 \\
108 \pm 7\end{array}$ \\
\hline Nylon/TD & Tear & $5 \times 10^{6}$ & ---- & $0.12 \pm 0.03$ & $0.29 \pm 0.02$ & $108 \pm 5$ \\
\hline \multicolumn{7}{|c|}{ Previous Results [4] } \\
\hline $\begin{array}{l}\text { LDPE/MD } \\
\text { LDPE/TD }\end{array}$ & $\begin{array}{l}\text { Tensile } \\
\text { Tensile }\end{array}$ & $\begin{array}{l}\text { None } \\
\text { None }\end{array}$ & -..- & $\begin{array}{l}4.1 \pm 0.40 \\
3.4 \pm 0.37\end{array}$ & $\begin{array}{l}8.2 \pm 1.0 \\
4.2 \pm 0.2\end{array}$ & $\begin{array}{l}225 \pm 60 \\
477 \pm 10\end{array}$ \\
\hline Nylon/TD & Tensile & None & -...- & $12.5 \pm 0.65$ & $18.0 \pm 1.4$ & $292 \pm 51$ \\
\hline $\begin{array}{l}\text { Nylon/TD } \\
\text { Nylon/MD }\end{array}$ & $\begin{array}{l}\text { Tensile } \\
\text { Tensile }\end{array}$ & $\begin{array}{l}5 \times 10^{6} \\
\text { None }\end{array}$ & ----. & $\begin{array}{l}13.1 \pm 0.11 \\
12.6 \pm 0.56\end{array}$ & $\begin{array}{l}13.2 \pm 0.2 \\
18.7 \pm 1.5\end{array}$ & $\begin{array}{r}97 \pm 35 \\
308 \pm 35\end{array}$ \\
\hline Nylon/MD & Tensile & $5 \times 10^{6}$ & -...- & $13.0 \pm 0.79$ & $15.9 \pm 2.1$ & $213 \pm 50$ \\
\hline
\end{tabular}

Note: Plus/minus indicates one standard deviation for sample of five measurements. 
Table 4. Significance of the Effect of Irradiation on Material Properties

Material/ Test Orientation Type

\begin{tabular}{ll}
\hline Upper Yield & \multicolumn{1}{c}{ Lower Yield } \\
Load
\end{tabular}

Effect

$\begin{array}{llllll}\text { HRMP/MD } & \text { Tensile } & -12 \% & -11 \% & -15 \% & -18 \% \\ \text { HRMP/TD } & \text { Tensile } & -17 \% & -14 \% & -27 \% & -29 \% \\ \text { Nylon/MD } & \text { Tensile } & -25 \% & -23 \% & -16 \% & \text { NSE } \\ \text { Nylon/TD } & \text { Tensile } & -27 \% & -20 \% & -28 \% & \text { NSE } \\ \text { HRMP/MD } & \text { Tear } & --- & -25 \% & -15 \% & +11 \% \\ \text { HRMP/TD } & \text { Tear } & --- & -10 \% & -25 \% & \text { NSE } \\ \text { Nylon/MD } & \text { Tear } & --- & -15 \% & -21 \% & \text { NSE } \\ \text { Nylon/TD } & \text { Tear } & --- & -42 \% & \text { NSE } & \text { NSE }\end{array}$

Previous Results [4]

$\begin{array}{llllll}\text { Nylon/MD } & \text { Tensile } & --- & \text { NSE } & -15 \% & -31 \% \\ \text { Nylon/TD } & \text { Tensile } & ---- & +5 \% & -27 \% & -67 \%\end{array}$

Note: Plus/minus indicates change from measured property of unirradiated sample. "NSE" means that the effect of irradiation is not significant at the $90 \%$ one-sided confidence level according to the Student's t test [7]. 
Tensile Test Sample

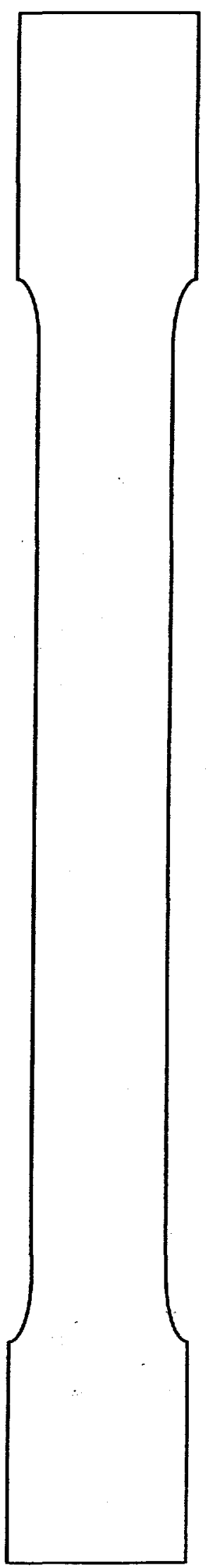

Tear Test Sample

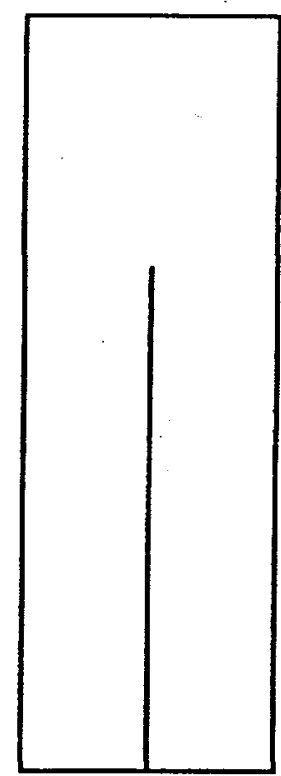

Figure 1. Tensile and Tear Test Samples (Drawings are approximately full-scale.) 